Theory and Line Spectra". Dr. Douglas Clark has written pointing out that his complete work has been subdivided for convenience in publication, and that an advertisement of the scheme printed as frontispiece shows that the concluding Part of Vol. 3 will deal with modern quantum mechanics. Papers relating thereto have been sorted for inclusion in Vol. 3, and the Part recently published contains the elassical treatment only. Thus while, in the opinion of the reviewer, modern quantum mechanies should have received attention already, Dr. Douglas Clark believes that his plan, which follows the historical order of development as far as possible, will prove satisfactory.

\section{Health Organisation of the League of Nations}

THE April number (7, No. 2) of the Bulletin of the Health Organisation is entirely devoted to the teaching of hygiene, based on a report by Prof. Jameson, Prof. Pittaluga and Dr. Stampar on certain European institutes and schools of hygiene. The June number (7, No. 3) contains papers on the assay of morphine and cocaine, the sero-diagnosis of syphilis, nutrition and nutritive requirements, and undulant fever in France. The final article deals with the significance of codeine as a habit-forming drug; this does not appear to occur, and the medical use of codeine is therefore not a social danger.

\section{Guide to Official Statistics}

THE annual volume entitled "Guide to Current Official Statistics of the United Kingdom" is now published for 1937 (London : H.M. Stationery Office. 18. net). The greater part of the book is a subject index in which every entry is followed by a list of related publications each referred to by its official number. This is followed by a numerical list of publications. The arrangement makes reference easy, and the book shows the wide range of valuable statistical and other matter that is available.

\section{Announcements}

THE Lord President of the Council has appointed Dr. G. Stafford Whitby, at present director of the Division of Chemistry, National Research Council, Canada, and formerly professor of chemistry at McGill University, Montreal, to be director of the Chemical Research Laboratory, Teddington, in succession to Sir Gilbert Morgan, who retired on September 30. Dr. Whitby is expected to take up his duties early in 1939.

THE Council of the Royal Society of Edinburgh, with permission of the Hon. Lord Robertson, have caused to be incised on the house at 14 India Street, Edinburgh, the following inseription:

\section{James Clerk Maxwell \\ Natural Philosopher \\ BORN HERE 13 JUNE 1831}

THE Hermann Göring foundation "Reichsjägerhof" has sent an expedition to Greenland for six or seven months investigation of animal and plant life as well as to make geographical and meteorological observa. tions.

AT a recent session of the Health Section of the League of Nations, an international commission was appointed to promote uniformity of standards for patent medicines. Dr. Charles H. Hampshire, of London, was appointed chairman, and the other members are Profs. H. Baggesgaard of Copenhagen, E. Zunz of Brussels, M. Tiffeneau of Paris, R. Eden of Zurich, L. van Italie of Leyden and Mr. Ernest Fullerton Cook of Philadelphia.

ONE of the Hunterian professorships of the Royal College of Surgeons of England has been awarded to Dr. Donald W. G. Murray, of Toronto, who will deliver his lecture in London next year. This is the second time that this award has been made to a Canadian, the other occasion being in 1924, when Dr. William E. Gallie, of Toronto, was so honoured. Dr. Murray has been appointed for his work on heparin, which has been done in conjunction with Prof. C. H. Best, professor of physiology in the University of Toronto.

Dr. Wu LIEn TeH, for thirty years in the Health and Medical Service of the Chinese Government, including the directorship of the Manchurian Plague Prevention Service and of the National Quarantine Service, recently retired to his home in Penang. He was editor of the National Medical Journal now known as the Chinese Medical Journal for fifteen years, and was founder and later president of the Chinese Medical Association.

THE Central Association for Mental Welfare has decided, with the approval of the Board of Control, to hold courses and establish a diploma for workers engaged in the teaching and training of low-grade mental defectives. The course will be held from January until December 1939, and the first two terms will be spent in approved occupation centres. The third term will be spent in London and will consist of theoretical and specialized practical work. Further information can be had from the honorary secretary of the Association, 24 Buckingham Palace Road, s.W.1.

According to official statistics, more sugar and margarine are consumed in Denmark than in any other country in the world. During the period 1930-34, the annual consumption of sugar in Denmark was $54 \mathrm{kgm}$. per inhabitant as compared with $49.5 \mathrm{kgm}$. in England, $46.3 \mathrm{kgm}$. in the United States, $25.6 \mathrm{kgm}$. in France and $10.3 \mathrm{kgm}$. in Poland.

THE Internationale Zeitschrift für Psychoanalyse and the journal Imago, the official organs of the International Psychoanalytic Society, which are both edited by Prof. Freud, have ceased publication. The International Journal of Individual Psychology is also suspending publication. 